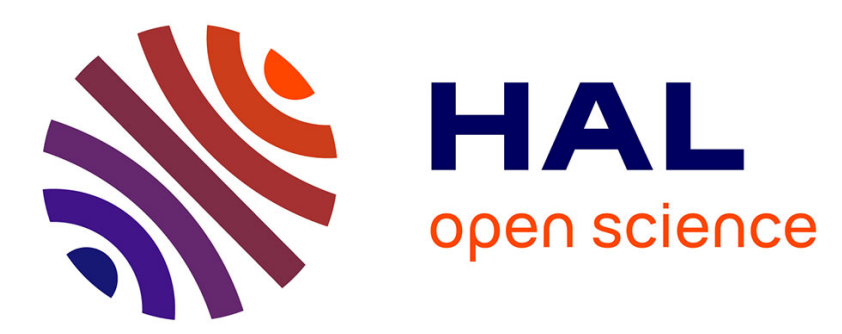

\title{
Controlling households' drilling fever in France: An economic modeling approach
}

Marielle Montginoul, Jean-Daniel Rinaudo

\section{To cite this version:}

Marielle Montginoul, Jean-Daniel Rinaudo. France: An economic modeling approach. 10.1016/j.ecolecon.2011.08.018 . hal-00680770
Controlling households' drilling fever in Ecological Economics, 2011, 71, pp.140-150.

\section{HAL Id: hal-00680770} https: / hal-brgm.archives-ouvertes.fr/hal-00680770

Submitted on 15 May 2020

HAL is a multi-disciplinary open access archive for the deposit and dissemination of scientific research documents, whether they are published or not. The documents may come from teaching and research institutions in France or abroad, or from public or private research centers.
L'archive ouverte pluridisciplinaire HAL, est destinée au dépôt et à la diffusion de documents scientifiques de niveau recherche, publiés ou non, émanant des établissements d'enseignement et de recherche français ou étrangers, des laboratoires publics ou privés. 


\title{
Controlling Households' Drilling Fever in France: an economic modeling approach
}

\author{
Marielle Montginoul et Jean-Daniel Rinaudo
}

\begin{abstract}
Using primary data collected at the national and local levels in France, this paper shows how water price increase, initially intended to generate environmental benefits through reducing water use, has produced economic incentives for households to drill their own garden boreholes. The paper first presents the results of a national survey which identifies the increasing number of garden boreholes as an issue of concern in a majority of the French counties. It then presents a microeconomic model which represents households' decision to construct a borehole. The model is used to simulate the impact of various water pricing scenarios on tube well development and residential water demand at regional level. The paper ends with a discussion of the social impact of emerging independent supply strategies.
\end{abstract}

Keywords: groundwater; household decision modeling; tube well; water pricing; water demand.

JEL classification: Q25, R22, Q51, C83, C61 


\section{INTRODUCTION}

During the last two decades, the use of economic instruments - taxes, pricing, and water markets - has been increasingly advocated as an effective solution for promoting water conservation, reducing water use and extraction, and for protecting water resources from over-exploitation and degradation (Rogers et al. 2002, Herrington 2007). In Europe, this new approach to water-resource management is reflected in recent policy initiatives taken by the European Commission (e.g., the Water Framework Directive) and by several Member States (European Commission 2000, Hrovatin and Bailey 2001). It is also reflected in water-price levels that have been rising significantly in real terms, as shown by the comparative studies carried out by OECD (OECD 1999, Herrington 2001, OECD 2010).

Empirical studies have confirmed that higher real volumetric prices for household water service induce a lower demand. The methodological approach implemented in these studies consists of collecting large cross-sectional or panel data sets for a few dozens to hundreds of local communities. Econometric techniques are then used to investigate the relationship between on the one hand, water consumption variables (explained variable), and on the other hand, households' socio-economic characteristics, housing characteristics, price of water, climate, etc. (explanatory variables). Price-elasticity figures reported in the literature typically range between 0 to -0.5 in the short run and between -0.5 to -1 in the long run (Espey et al. 1997, Arbués et al. 2003, Dalhuisen et al. 2003, Worthington and Hoffman 2008, Schleich and Hillenbrand 2009). In France, several studies have estimated the price elasticity of residential water demand at about -0.2 (Nauges and Thomas 2003, Reynaud and Nauges 2010, Rinaudo et al. forthcoming).

Price-elasticity values estimated by econometric techniques are often used by practitioners to simulate future water demand for a range of water-tariff scenarios. A variety of simulation approaches are implemented, ranging from the simple point expansion method (Jenkins et al. 
2003) to sophisticated modeling software such as IWR-MAIN (Institute for Water Resources

- Municipal And Industrial Needs) developed and used in the US (Ortiz et al. 1997). However, none of these modeling approaches considers how household water usage changes in response to water price increases. It is generally assumed that users first reduce losses in their homes (e.g., by fixing leaks) and then adjust certain practices (e.g. by taking shorter showers and fewer baths). A second-stage adjustment may consist of installing water-saving devices (dual-flush WCs), investing in more water-efficient equipment (dishwasher, washing machine), changing their garden landscaping and/or investing in more efficient garden irrigation systems.

Price increases may also generate strong incentives for households to substitute an alternative water supply technology to that provided by the utility service. Above a certain price level, it may be economically profitable to use cheap, low-quality water as a substitute for expensive drinking water, for all uses which do not require high water quality (watering of gardens, toilet flushes, etc.). The choice of the alternative decentralized supply technology depends on the local technical, economic, climatic, and environmental context. In some regions of the world, households have invested in rainwater-recovery systems (Herrmann and Schmida 1999, Australian Bureau of Statistics 2004). In rural areas, households may try to obtain a pipe connection to irrigation-water supply systems (see (Montginoul et al. 2009) for a French example and (Sociology Water Lab and Colorado Institute for Irrigation Management 2003) for a US example). In California and Australia, households may use recycled water distributed by Water Districts (Lazarova et al. 2003, Anderson 2006). Drilling and installing private tube wells in gardens is another possible strategy which is reported in several countries such as the Netherlands (Meij et al. 2005), Germany (Schleich and Hillenbrand 2009), Belgium (Aquawal, 2009) and Australia (Appleyard et al. 1999, Australian Bureau of Statistics 2004). The intensity of substitution may depend on the quality of alternative water resources: a low- 
Author-produced version of the article published in Ecological economics, 2011, 71, 140-150.

The original publication is available at http://www.sciencedirect.com

Doi: 10.1016/j.ecolecon.2011.08.018

quality alternative water resource will be used only for watering gardens, but if the quality of the substitute is up to local drinking-water quality standards, households may totally shift from public to private water supply.

In Europe, the proportion of households investing in a private water-supply system should significantly increase in the coming decade, as a result of increased water scarcity, higher tariffs from public water supplies, and the decreasing cost of alternative supply technologies (recycling in particular). A new generation of water demand simulation models therefore needs to be developed to describe this phenomenon. These models need to explicitly represent the behavioral, operational, and investment decisions of households, considering the socioeconomic heterogeneity of any population of water consumers. The modeling framework developed by (Rosenberg et al. 2007) to simulate water demand in an intermittent supply system in Jordan is in this regard a very inspiring example.

This paper focuses on the substitution issue in a French context where a growing number of households are establishing private garden tube wells. We develop a behavioral model representing the household investment decision, and use it to simulate the impact of changes in public supply tariffs on tube-well development and water demand. The behavioral model is integrated into a database to estimate the aggregate impact on water demand of tube-well construction at the municipal level. A numerical application is carried out for a sample of 186 municipalities in Southern France. The model is then used to simulate how various economic instruments could be used to control the development of private tube wells.

This paper is organized as follows. In Section 2, we describe the risks and management problems caused by the increasing number of garden boreholes, using the results of a national survey conducted by the authors with 114 representatives of decentralized administrations and local governments in France. The paper then goes on to present the micro-economic behavioral model representing the household decision to invest in a tube well (Section 3). 
Section 4 presents the case study and the results of the numerical application of the model. The model is then used to simulate the impact of various scenarios of change in the economic and regulatory environment (Section 5). In a concluding section, we discuss the social implications of the progressive development of autonomous water supply systems such as private tube wells.

\section{THE DEVELOPMENT OF DOMESTIC BOREHOLES IN FRANCE}

\subsection{French context}

In France, it was only in the early 1990s that policy makers started to consider water pricing as a policy instrument for managing water demand and recovering costs. The principle of cost recovery for water services was first introduced with the 1992 Water Law which compelled municipalities to keep and balance a separate budget for water services, so that consumers would pay the true cost of water. The law also forbids municipalities from using flat-rate tariffs (with a few limited exceptions). These changes were reinforced in the 2006 water law. As a result, the price paid by water users in France has drastically increased. Between 1991 and 1997, the average water bill (calculated for a consumption of $120 \mathrm{~m}^{3} /$ year/household) rose by seven per cent per year on average (DGCCRF 1999). This trend has continued since then, but with a lower growth rate; for instance, it is about $2 \%$ per year for 2001-2004 (IFEN 2007)

Preliminary investigations conducted by the authors in several regions of France between 2000 and 2005 found that this price increase has created strong incentives for households to install private tube wells. However, since households were not compelled to declare their wells, no statistical data exist to assess the scope of this phenomenon.

To fill this gap, we undertook a national mail survey, targeting selected public experts involved in urban water management in each of the 96 metropolitan French counties ("départements" in French). The experts consulted were drawn from: (i) the Government 
Department for Social, Heath and Sanitation Affairs (DDASS), responsible for implementing laws and regulations related to drinking water; (ii) the Government Department for Agriculture and Rural Affairs, responsible for supporting small and medium municipalities with regard to issues related to investment in the water and sanitation sector; (iii) County Councils (“Conseils Généraux") which administer the National Solidarity Funds for Water Supply Development at the county level; and (iv) County-level associations of mayors, likely to be aware of the difficulties faced at the municipal level for all water-related issues (the drinking-water supply being the mayor's responsibility in France). All these experts are well aware of problems occurring at the local level, since they either control or provide technical support to municipal water utilities. They were asked to give their views on: the level and the changes (past and future) in private tube-well development in the county; the opportunities and problems caused; and the strategies implemented by various public actors to control the development of individual water-supply systems. A total of 114 complete questionnaires were returned, covering 78 counties. The following paragraphs present the main results of this survey.

\subsection{Intensity of the phenomenon}

The presence of domestic tube wells (or shallow wells) is reported in $85 \%$ of the 78 French counties covered by the survey. Contrary to our expectation, there is no clear relationship between the presence of tube wells and the geographic and climatic characteristics of the counties: the presence of tube wells is not limited to the southern part of France, where water needs in summer are really high: cases of tube well development are also reported in the north of France (Figure 1). 


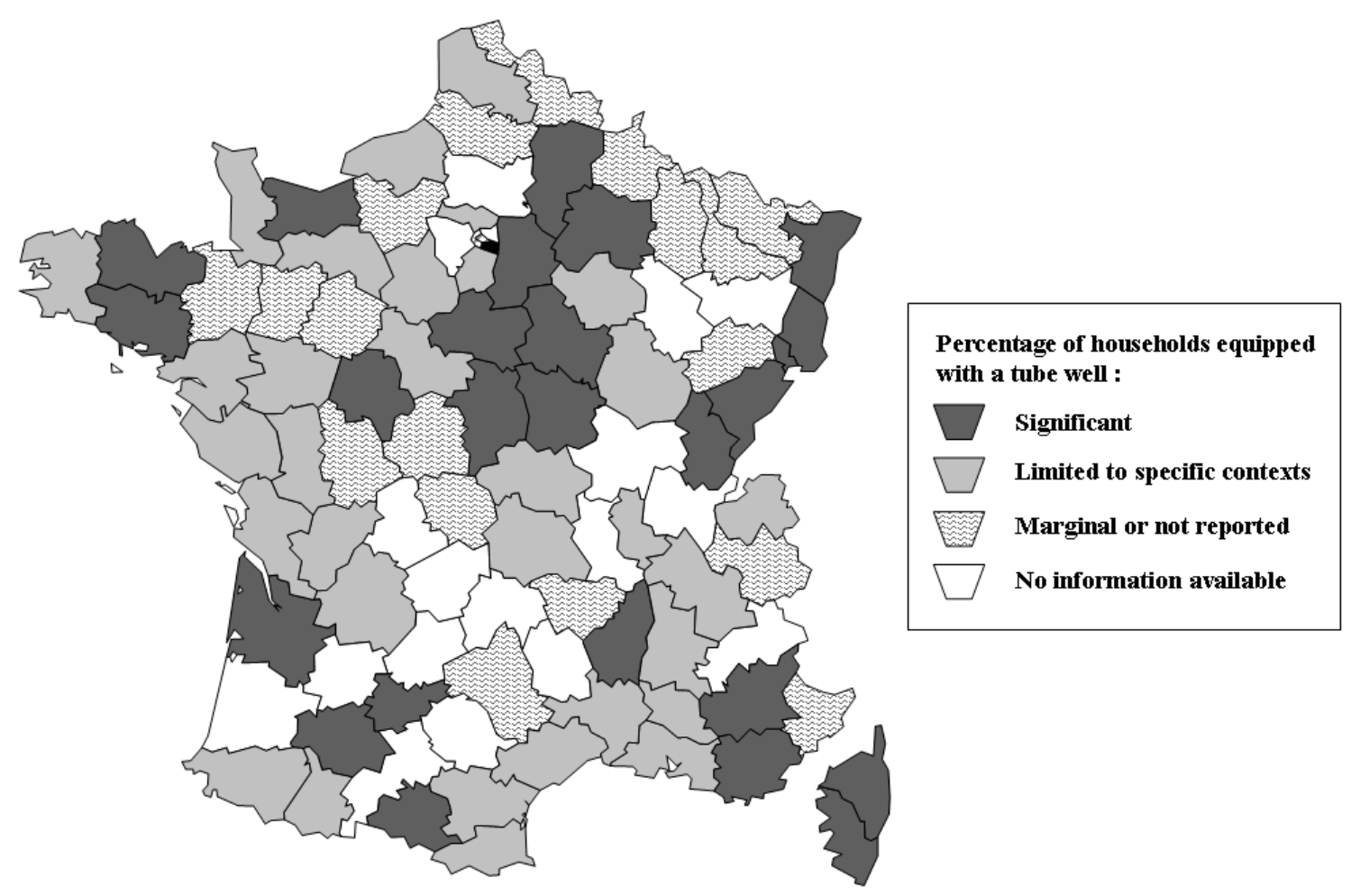

Figure 1: French counties where the presence of domestic tube wells is reported

A large majority of the experts consulted (61\%) consider that the problem is due to inadequate regulation and lack of political will to enforce existing legal provisions. In France, the construction and operation of private tube wells for domestic use is not as regulated as it is in most other European countries or in many US States. Contractors can drill without obtaining a specific license and boreholes can be established without requesting a permit. The only constraint imposed by the Mining Code (Article 131) is the obligation for the tube-well's owner to submit a drilling report to the Government Department for Mining and Industry and to the French Geological Survey (BRGM), specifying the location of all boreholes deeper than ten meters together with a description of the geology at the well site (drilling log). Since January 1, 2009 households are also required to declare their wells to the municipality. However, examination of existing databases operated by the French Geological Survey indicates that wells are rarely declared. Similarly, groundwater extraction by households is 
Author-produced version of the article published in Ecological economics, 2011, 71, 140-150.

The original publication is available at http://www.sciencedirect.com

Doi: 10.1016/j.ecolecon.2011.08.018

not constrained by law if less than 1,000 cubic meters are extracted per year - which is generally the case for most households.

\subsection{Problems caused by the development of private tube wells}

Most of the experts consulted (90\%) are seriously concerned about the uncontrolled development of private tube wells. Four main areas of concerns are identified:

Environmental risk. The development of domestic tube wells may cause an overexploitation of tapped aquifers, leading to a drop in water tables, land subsidence and, in coastal areas, to seawater intrusion. Such cases of seawater intrusion due to "drilling and pumping fever" have also been reported by (Aguilera-Klink et al. 2000) on the island of Tenerife and by (Kent et al. 2002) in Mallorca. In urban areas, the problem of over-exploitation of shallow aquifers by private tube wells is exacerbated by the fact that urbanization leads to an increase of impervious surfaces (paved roads, parking lots, and roofs) which prevent rainwater from infiltrating into the ground. Moreover, private tube wells represent a significant risk of pollution for high-quality confined aquifers exploited for drinking-water production mainly because they are not always constructed according to standards (a fact which is confirmed by (Miquel and Revol 2003)). To reduce tube-well prices, certain drilling companies do not install the cemented casing that is required to ensure that no communication exists between the various aquifer layers intersected by the borehole. As a result, tube wells often connect previously separate hydrogeological layers at hundreds - if not thousands - of points, thereby allowing good-quality aquifer layers to become contaminated by polluted shallow aquifers.

Public-health risk. Some households may substitute cheap untreated groundwater for expensive drinking water for indoor uses, such as toilet flushing and washing machines, but also in showers and sometimes in cooking. Technically, this simply requires that a dual-pipe network be installed in the house. The regular inhalation of water aerosols (in showers) or ingestion of water (drinking, cooking) may be hazardous, since aquifers tapped by households 
Author-produced version of the article published in Ecological economics, 2011, 71, 140-150.

The original publication is available at http://www.sciencedirect.com

Doi: 10.1016/j.ecolecon.2011.08.018

may be affected by the most common forms of diffuse and point-source pollution (nitrates and pesticides, chlorinated solvents, polycyclic aromatic hydrocarbons, etc.). Also the construction of dual systems that enable indoor use of untreated groundwater creates a risk of contamination of the municipal drinking-water system by poor-quality groundwater. This risk is due to the fact that, in most houses equipped with a dual system, the drinking-water and untreated-water plumbing systems are not totally separate but interconnected (despite this being strictly prohibited by French law). Incorrect manipulation of the valve that separates the two plumbing systems results in backflow of water pumped from the tube well (high pressure) towards the public system (low pressure). Such incidents are frequently reported and represent a major concern for public and private drinking-water utilities.

Risk for planning. The development of private tube wells, which results from individual choice, is quite difficult to forecast. As a consequence, it is extremely hard for municipal authorities and water utilities to predict future demands for drinking water and to plan investments and system developments accordingly. The French experts we consulted report that many municipal authorities have over-estimated the drinking-water demand and constructed over-sized infrastructures because they did not foresee the development of hundreds of tube wells by households ${ }^{1}$. To balance their budget, they were compelled to implement sharp increases in the water price, which has in turn provided incentives for households to drill more boreholes. Another source of uncertainty is also reported: during periods of drought (such as the 2003 summer in France), hundreds of domestic tube wells tapping shallow aquifers may run dry. The households concerned then compensate for the temporary failure of their own water-supply system through a significant increase in drinkingwater use. This results in a drastic increase in total drinking-water demand that public utilities

\footnotetext{
${ }^{1}$ This is also reported in other European contexts (Meij et al., 2005).
} 
may not be able to satisfy - unless they had decided to over-size their system to be able to face such a crisis.

Financial risk. The indoor use of untreated groundwater (for toilet flushes, washing machines, etc.) creates financial difficulties for utilities operating wastewater-treatment plants, who generally charge users according to the volume of drinking water they consume. Households having private tube wells consume very little drinking water, and thus pay very low sanitation charges although they discharge a significant volume of wastewater. When the proportion of households using tube wells increases, the cost-recovery ratio (for the sewage service) deteriorates, which forces the manager to raise water and sewage charges. This causes inequities, since the bulk of the total sewage cost is paid by households which do not have their own water supply.

\subsection{Threat or opportunity?}

A limited number of our experts consider that the development of private tube well may also be an opportunity both for water managers and consumers, and lead to enhance welfare in specific contexts. From a public utility perspective, the presence of tube wells reduces total domestic demand for treated drinking water, with two positive impacts. First, it reduces extraction from the high-quality confined aquifers used by public water utilities, when households mainly tap shallow aquifers for garden irrigation. Second, costly investments that would otherwise be required are avoided, since the total capacity of the distribution system can be kept at a minimal level ${ }^{2}$. The savings in terms of water resources and public investment are particularly significant in areas, where most of the population lives in detached or semidetached houses with gardens and/or swimming pools, and where outdoor uses represent a sizeable share of total water consumption. Also, because outside uses are concentrated over a

\footnotetext{
${ }^{2}$ In practice, the presence of private tube wells will not significantly decrease investment needs for two reasons. Firstly, households equipped with a borehole will still ask for a connection to water mains as the cost is entirely borne by the municipality; there will thus be no saving in terms of distribution network. Secondly, water utilities
} 
short time period in summer, the development of domestic tube wells contributes to reducing the peak demand which determines the dimensions of the distribution system.

A non European illustration of this positive impact is provided by the case of the city of Perth in Western Australia (Appleyard et al. 1999, Saayman and Adams 2002). In this city, the number of private tube wells is estimated at 150,000 (one house in four has drilled a well, a figure confirmed by the Australian Bureau of Statistics, 2004), resulting in a yearly reduction in total drinking-water demand of 184 million cubic meters. In some extreme cases, experts may go as far as recommending that public authorities encourage (e.g., through subsidies) the development of private tube wells (see for instance (Saayman and Adams 2002), for the case of Cape Town). This, however, ignores the multiple environmental threats, health risks, and public-utility management problems caused by the uncontrolled increase of domestic tube wells.

From a household perspective, the construction of private boreholes can theoretically result in reduced water bill, thus increasing consumer economic surplus. The benefits are however not likely to be equitably shared among consumers. Indeed, as the total volume of water sold decreases, the Water Utility will have to compensate the loss of revenue by increasing price, in order to cover fixed costs (which represent $80 \%$ of production costs). Households living in apartment flat, who do not have the possibility to drill, will end-up paying higher water bills whereas borehole owners will benefit from an increased net economic surplus.

\section{MODELING THE HOUSEHOLD DECISION}

\subsection{The household' decision-making process}

To understand how households decide to drill a well, the authors conducted a series of faceto-face detailed interviews with 55 households (including 36 having boreholes) living in the

will always oversize production and distribution equipment to make sure they can supply the population, even if private (shallow) tube wells run dry during drought periods. 
Author-produced version of the article published in Ecological economics, 2011, 71, 140-150.

The original publication is available at http://www.sciencedirect.com

Doi: 10.1016/j.ecolecon.2011.08.018

municipality of Canet, considered as representative of fast developing sub-urban areas in the region $^{3}$. We cross-checked the information obtained from households with 15 professionals from drilling companies operating in the region. Interviews, lasting for one hour or more, were guided by a semi-structured questionnaire. The description by households of how they decided to drill (or would envisage doing so) concurs with the vision by professionals of how their customers decide to invest. Saving on the water bill appeared as the main motivation for drilling $^{4}$. The households we met had all carried out a basic assessment of the profitability of their investment by comparing the expected cost of drilling with the expected savings on the water bill. Parameters considered are the yearly average water use, water and sanitation tariffs, the cost of drilling, and the pumping cost. Most of the households overestimate the service life of the tube well, underestimate the pumping power and maintenance costs, and do not employ any discount rate in their calculations. They generally base their calculations on the assumption that groundwater will be used only outdoors (for garden watering, car washing, swimming-pool filling, etc) and that they will continue using drinking water indoors (kitchen, showers, toilets, etc). Some of them however plan to install a dual system indoors in order to use untreated (cheap) groundwater for toilet flushing, washing machines, and possibly showers, and to reduce drinking-water consumption to a minimum. Households are apparently aware of the uncertainty related to the depth at which groundwater can be found, their perception of the level of uncertainty being based on direct observation (depth to which neighbors have drilled a well) and information provided by the drilling company or the regional office of the National Geological Survey (BRGM). Finally, some households take

\footnotetext{
${ }^{3}$ This municipality is representative of the area where, due to rapid demographic growth, the issue of residential water demand forecasting and management is a serious issue of concern. Located $40 \mathrm{~km}$ away from the city of Montpellier, this medium size municipality (over 2000 inhabitants) hosts a large population of commuters attracted by relatively low land price. Incoming households systematically construct a detached house with garden and often a swimming pool. This new population co-exists with households living in older houses of the much denser historical part of the village. As in most villages of that type, there are no multi-storey buildings. Groundwater is easily accessible and boreholes can be constructed at a reasonable price.
} 
into account possible future trends in drinking-water prices (upward trend expected to continue) when performing their calculation.

\subsection{Modeling principle}

The behavioral model representing a household's decision to drill was developed based on these interviews. The model assumes that individual households decide to install a tube well if the total annual cost of groundwater exploitation (capital and recurring costs) is lower than the expected savings on their water bill. The total annual cost $\left(\mathrm{C}_{\text {annual }}\right)$ of tube-well operation and the expected annual savings $\left(\mathrm{S}_{\text {annual }}\right)$ may be expressed as follows:

$$
C_{\text {annual }}=c H \times \frac{a(1+a)^{T}}{(1+a)^{T}-1}+p_{g} Q
$$

and

$$
S_{\text {annual }}=Q \cdot p_{d}
$$

where:

$H$ is the depth at which groundwater can be obtained (in meters), and $\mathrm{H}$ identifies the investment and the pumping costs;

$T$ is the expected lifetime of the tube well and pumping equipment (in years);

$a$ is the discount rate;

$c$ is the drilling cost (in $€ /$ meter) which depends on the type of aquifer;

$Q$ is the volume of water for which substitution is possible (in $\mathrm{m}^{3} /$ year);

$p_{d}$ is the marginal price of water from the public supply (including wastewatertreatment charges and taxes, (in $€ / \mathrm{m}^{3}$ );

$p_{g}$ is the cost of groundwater pumping (in $€ / \mathrm{m}^{3}$ ).

The construction of a tube well is a profitable investment when the volume of water for which substitution is possible is equal to (or greater than) a threshold value $\mathrm{Q}_{\min }$ which is such that the expected saving $\mathrm{S}$ is equal to the expected $\operatorname{cost} \mathrm{C}$, or:

$$
Q_{\min }=\frac{c . H}{\left(p_{d}-p_{g}\right)} \times \frac{a(1+a)^{T}}{(1+a)^{T}-1}
$$

\footnotetext{
${ }^{4}$ Other motivations include: the desire to use more water at a constant cost, the willingness to be autonomous in terms of water supply, ecological motivations (why waste treated water for irrigating turf?), the possibility to continue irrigating when restrictions are imposed on irrigation water use.
} 
Author-produced version of the article published in Ecological economics, 2011, 71, 140-150.

The original publication is available at http://www.sciencedirect.com

Doi: 10.1016/j.ecolecon.2011.08.018

\subsection{Taking uncertainty into account}

Given the uncertainty surrounding the depth at which water will be reached, and the risk of failure (dry hole), the investment cost (C) and the amount of savings achieved on bills (S) are uncertain decision parameters. Two sources of uncertainty should be distinguished. The first is linked to the risk of not finding water in the aquifer layer targeted. This risk depends on the geology: the likelihood of success $(Л)$ is lower on a Jurassic limestone plateau (0.2 to 0.3 ) than in the Miocene formations of the Hérault plain's terraces ( 0.4 to 0.6$)$, or than in the Quaternary alluvial deposits of the Hérault Valley (0.8 to 0.95$)$. Information gathered by the survey clearly showed that households are aware of this risk, and that they consider it when making their decision, by anticipating drilling down to the second aquifer layer in case of a failure to find water in the first one.

The second source of uncertainty is linked with the variability of the depth $H$ at which water can be found in any particular aquifer layer targeted. This variability is higher in fractured or strongly heterogeneous aquifer layers (limestone, marl, and complex alluvial deposits) but is much lower in more homogenous environments such as sands (e.g., the sand layers of Astien on the coastline) or Quaternary alluvial deposits. As the interviews suggest, households are aware of this uncertainty: when assessing the financial profitability of a borehole project, they base their calculations on subjective depth hypotheses. This subjective hypothesis, which we will call "depth expectancy" here, varies from one individual to another depending on their perception of the risk. Thus, a household whose income is small is assumed to have a larger aversion to risking such an undertaking than a household whose bigger financial resources would mean that a failure would not have serious consequences for them. Depth expectancy ( $\widetilde{H})$ is assumed to be equal to the average depth $(\bar{H})$ at which water can be found (value based on objective data) increased by a subjective depth (the risk premium) equal to the standard deviation $(\sigma)$ multiplied by the risk aversion coefficient $(\Phi)$. This approach is 
Author-produced version of the article published in Ecological economics, 2011, 71, 140-150.

The original publication is available at http://www.sciencedirect.com

Doi: 10.1016/j.ecolecon.2011.08.018

inspired by behavioral models developed by (Freund 1956) which depicts farmers' croppingpattern decisions in situations of market or resource uncertainty and by (Markowitz 1952) representing the decisions of agents in uncertain financial markets. In the present case, $\Phi$ is calibrated by using observations made in the Canet municipality, which is the only location for which we have an accurate estimate of the number of boreholes.

$$
\widetilde{H}=\bar{H}-\Phi \sigma
$$

These two sources of uncertainty impact the expected investment cost. If the first aquifer layer $\mathrm{A}_{1}$ is productive (probability $\Omega_{1}$ ), the cost is equal to the depth at which water is expected to be found, $\widetilde{H}_{1}$ multiplied by the cost per linear meter of borehole drilling and well casing. If the first layer is unproductive (probability $1-\Omega_{1}$ ), the borehole must be drilled deeper to reach the second aquifer layer at $\widetilde{H}_{2}$. Assuming that this second layer is productive (probability $\left.\Omega_{1} \Omega_{2}\right)$, the cost is equal to the depth reached multiplied by the cost per linear meter of borehole drilling and well casing. Otherwise, if the hole is a dry one (probability equal to [1$\left.\left.\Omega_{1}\right] .\left[1-\Omega_{2}\right]\right)$, the cost is equal to the depth reached multiplied only by the cost per linear meter of borehole drilling (the well does not need casing in this event). In this worst-case scenario, the amount spent represents an irreversible financial loss for the household, which must continue to be supplied with urban water.

Then the annual expected cost $\left(\widetilde{C}_{\text {annual }}\right)$ is defined as the sum of the cost of each event described above multiplied by the probability of its occurrence, as follows:

$$
\begin{aligned}
\widetilde{C}_{\text {annual }} & =A \times\left[\pi_{1} \cdot c_{1}\left(H_{1}+\Phi \sigma_{1}\right)+\left(1-\pi_{1}\right) \pi_{2} \cdot c_{2}\left(H_{2}+\Phi \sigma_{2}\right)+\left(1-\pi_{1}\right)\left(1-\pi_{2}\right) \cdot \frac{c_{2}}{2}\left(H_{2}+\Phi \sigma_{2}\right)\right] \\
& +Q\left[\pi_{1} p_{g}+\left(1-\pi_{1}\right) \pi_{2} p_{g}+\left(1-\pi_{1}\right)\left(1-\pi_{2}\right) p_{d}\right]
\end{aligned}
$$

where $A=a \times \frac{(1+a)^{T}}{(1+a)^{T}-1}$ is the discount factor and a is the discount rate; $\mathrm{H}_{1}$ and $\mathrm{H}_{2}$ are the average depths of water in the first and second aquifers; $c_{1}$ and $c_{2}$ are the drilling costs per 
Author-produced version of the article published in Ecological economics, 2011, 71, 140-150.

The original publication is available at http://www.sciencedirect.com

Doi: 10.1016/j.ecolecon.2011.08.018

meter for the first and second aquifers; $\Phi$ is the household's risk aversion coefficient; $p_{d}$ is the price charged per cubic meter for drinking water supply and sanitation services; $\mathrm{p}_{\mathrm{g}}$ is the pumping cost in the tube well per cubic meter extracted; $Q$ is the quantity of water for which a resource substitution is possible (outdoor uses, possibly toilet uses and washing machine).

Using these symbols, and after simplification, the minimum yearly volume of water to be pumped (the profitability threshold $\mathrm{Q}_{\mathrm{min}}$ ) may be expressed as follows:

$Q_{\min }=\frac{\pi_{1} c_{1}\left(\bar{H}_{1}+\Phi \sigma_{1}\right)-\frac{c_{2}}{2}\left(\bar{H}_{2}+\Phi \sigma_{2}\right)\left(\pi_{1}-\pi_{2}+\pi_{1} \pi_{2}-1\right)}{\left(p_{d}-p_{g}\right)\left(\pi_{1}+\pi_{2}-\pi_{1} \pi_{2}\right)} \times \frac{a(1+a)^{T}}{(1+a)^{T}-1}$

This threshold value $\mathrm{Q}_{\min }$ is a function of parameters which are assumed to be uniform across households for each municipality. Its actual value was then calculated for a sample of municipalities for which the required information had been collected.

\subsection{Modeling the impact of individual decisions on total water demand}

A second module was then developed to assess the cumulative impact of household decisions on total water demand at the municipal level. This model uses as input (i) the demographic and housing characteristics of each municipality, (ii) a water-demand profile, and (iii) the tube well profitability threshold $\left(\mathrm{Q}_{\mathrm{min}}\right)$ estimated by the behavioral model. As outputs, it assesses the number of households likely to drill a borehole in the municipality and estimates the corresponding minimum volume of raw water likely to be pumped (if there is no change in water consumption behavior) from the aquifer - and the related decrease in urban water demand. The two modules are linked to a database describing the hydrogeological, economic, and demographic characteristics of municipalities. A scenario generator is then connected to the model, enabling an assessment of the impacts of various scenarios (Figure 2). The combined model can then be used to simulate the impacts of such scenarios (including changes in the urban water-pricing level and structure) on total drinking water demand. 


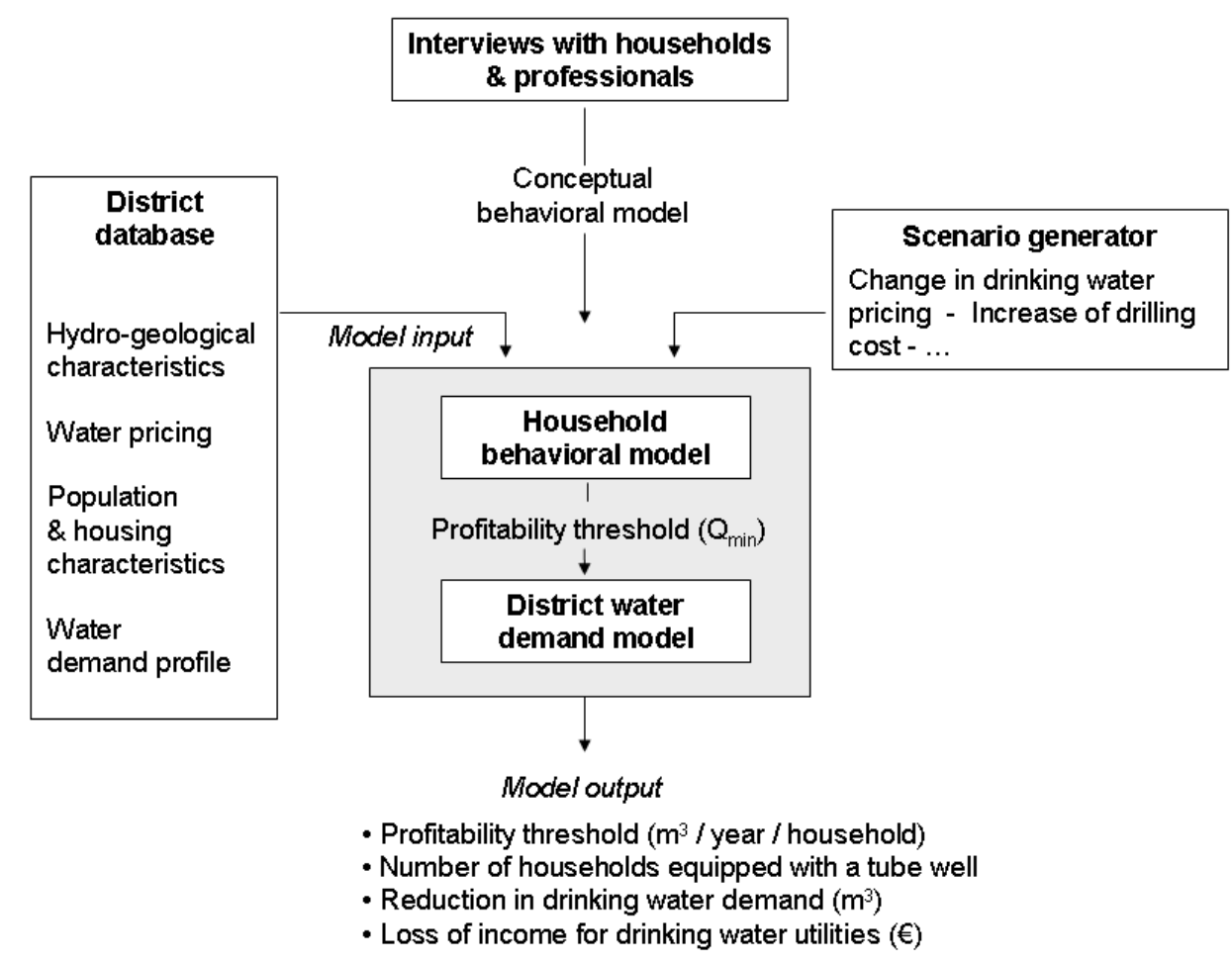

Figure 2: General structure of the economic model

The water-demand modeling principle is the following. For a given municipality where the tube-well profitability threshold $\left(\mathrm{Q}_{\min }\right)$ has been estimated from the behavioral model, the Water-Demand Model assesses the number of households $\mathrm{N}_{\text {bore }}$ likely to drill a borehole and the corresponding reduction in urban water demand. The estimate relies on the assumption that households will drill a borehole if their current yearly water consumption for outdoor uses (garden watering, swimming pool) is higher than $\mathrm{Q}_{\min }$. We further assume that households equipped with a borehole will continue to use a minimum of $50 \mathrm{~m}^{3}$ per year of drinking water for cooking, drinking, showers, etc. This implies that only households consuming more than $\left(Q_{\min }+50\right) \mathrm{m}^{3} /$ year will invest in a tube well.

The number of households $\mathrm{N}_{\text {bore }}$ is estimated using the municipality's water-demand profile, defined as the distribution of households by classes of water consumption (Figure 3). The current water consumption of the $\mathrm{N}_{\text {bore }}$ households, noted $\Delta \mathrm{V}_{\text {bore, }}$ is also estimated from the 
Author-produced version of the article published in Ecological economics, 2011, 71, 140-150.

The original publication is available at http://www.sciencedirect.com

Doi: 10.1016/j.ecolecon.2011.08.018

water-demand profile ( $\Delta \mathrm{V}$ is graphically represented by the shaded area on the right hand side of the distribution).
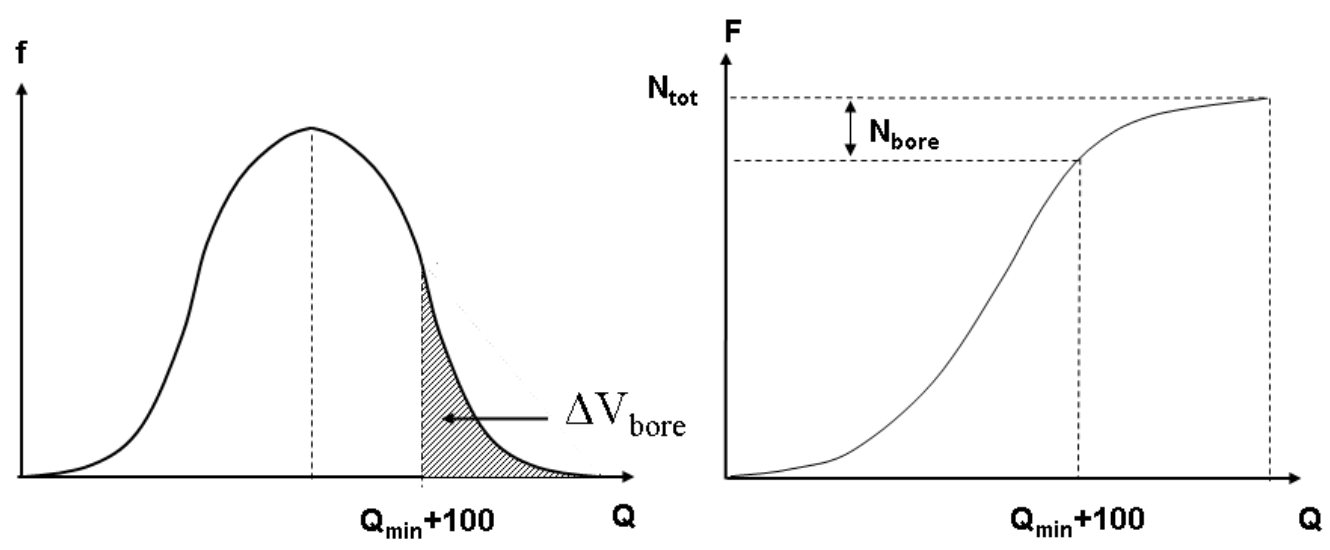

$\mathbf{Q}$ is the water consumed per household in $\mathrm{m}^{3}$.

$\mathbf{f}$ is the frequency of urban water consumption.

$F$ is the cumulative frequency of urban water consumption.

$\mathbf{N}_{\text {bore }}$ is the number of households for whom drilling a borehole is a profitable option.

$\mathbf{N}_{\text {tot }}$ is the number of households living in the municipality.

$\Delta \mathbf{V}_{\text {bore }}$ (area shaded in gray) is the current urban water consumption of households for which drilling a borehole is a profitable option.

Figure 3: Distribution of households per class of water consumption (water demand profile)

To assess the reduction in urban water demand, we further assume that only $80 \%$ of the households in question will actually drill a borehole (the remaining $20 \%$ do not invest either because they face cash-flow constraints, or because access of the drilling machine to the garden is not possible or would generate too much damage to the vegetation in case of landscaped gardens). ${ }^{5}$ The model estimates the reduction in urban water demand due to the presence of boreholes. It also estimates the loss of income for the urban water utility, taking into account pricing information for the water and sewerage services.

A typical water-demand profile, defined as the standard distribution of households per classes of water consumption, is constructed by using water-billing records (892 customers, including 
Author-produced version of the article published in Ecological economics, 2011, 71, 140-150.

The original publication is available at http://www.sciencedirect.com

Doi: 10.1016/j.ecolecon.2011.08.018

372 in detached houses) collected in Canet. This water-demand profile is then adjusted to each of the 186 municipalities, using demographic and housing data.

\section{CASE STUDY AND NUMERICAL APPLICATION}

\subsection{Characteristics of the case-study area}

The model was applied to a coastal area in the Languedoc-Roussillon region, covering 310 municipalities and about 5,000 square kilometers. The area is characterized by a high demographic growth rate (1.6\%/year) mainly due to migration from the North of France and other European regions. Migrants generally settle in detached or semi-detached houses, almost always with gardens and very often a swimming pool. Faced with increasing water demands generated by this demographic influx, municipal water utilities have made significant investments in the drinking-water sector (new groundwater extraction works, new tanks, extension of the distribution system, etc.). The resulting water-price increase and the fear that this trend would continue has caused many households to build their own garden tube wells, in particular in areas where underground water is relatively easily accessible.

\subsection{Model numerical application}

Data needed to run the economic model were collected for a sample of 186 municipalities (out of 310) for which we calculated the threshold value $Q_{\min }$. These municipalities are representative of the diversity of geological context (Jurassic limestone bedrock, alluvial deposits, Astien sands, Miocene marl) and of price levels in the region. Urban water price data were collected by means of a large mail survey. A detailed analysis of the geological map and borehole data available at the French Geological Survey (BRGM) was then conducted to identify the nature of the first two aquifer layers in each municipality (average depths, standard deviations, and the risk of a dry hole). Demographic and housing data were taken

\footnotetext{
${ }^{5}$ The choice of $80 \%$ as a value for this parameter is based on expert judgment. It should thus rather be considered as an informed guess than a scientifically validated assumption. However, considering the lack of
} 
Author-produced version of the article published in Ecological economics, 2011, 71, 140-150.

The original publication is available at http://www.sciencedirect.com

Doi: 10.1016/j.ecolecon.2011.08.018

from the most recent population census, carried out in 2006 by the National Institute for Statistics and Economic Studies (INSEE). The information collected concerns the number of households, type of occupancy (permanent or temporary), and type of housing (detached houses or apartment buildings, with or without gardens).

Results show that the profitability of borehole drilling varies widely in the sample (Figure 4). The threshold volume is lower than $70 \mathrm{~m}^{3}$ in only one municipality, where it represents a profitable investment for almost any owner of a detached house. The threshold ranges between $120 \mathrm{~m}^{3}$ and $250 \mathrm{~m}^{3}$ for another $17 \%$ of the municipalities where boreholes may attract owners of detached houses with small to medium sized irrigated gardens and a swimming pool. In $21 \%$ of municipalities, the threshold ranges between 250 and $500 \mathrm{~m}^{3}$, meaning that only owners of houses with large and intensively irrigated gardens are likely to drill a borehole. Above $500 \mathrm{~m}^{3}$, drilling a borehole is not a profitable investment and no household is expected to drill (62\% of the municipalities).

empirical data, there was no other way than relying on expert judgement to assess this percentage. This is what we did, preferring to take the risk of assuming a value rather than ignoring the phenomena. 


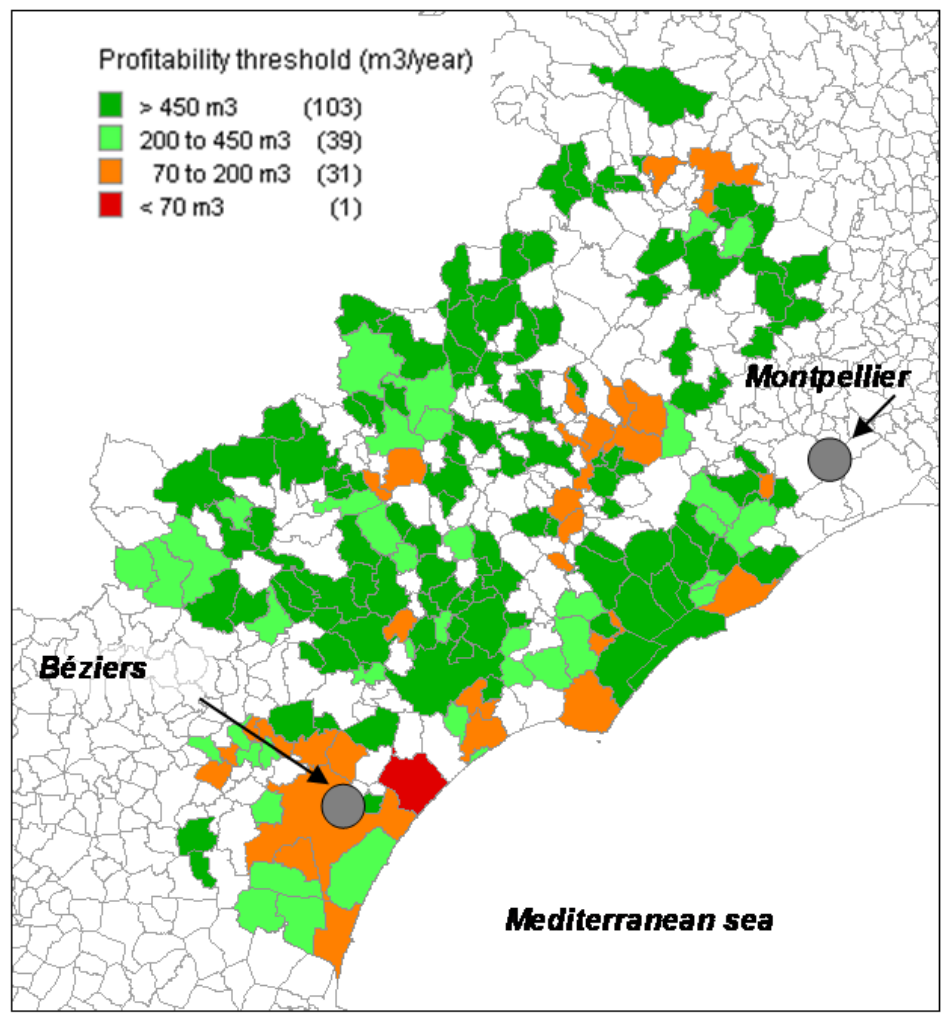

Figure 4: Estimated profitability threshold in the 2006 reference situation ( $\mathrm{m}^{3} /$ year/household)

The total number of boreholes is estimated at 6,800 in the entire case-study area. Their density differs significantly from one municipality to another (Table 1). The model predicts that no or very few - boreholes should have been drilled in 108 municipalities. At the other extreme, borehole density is relatively high in 18 municipalities where 25 to $50 \%$ of the owners of detached houses are likely to have drilled. The situation is even more extreme in 7 municipalities, where more than $50 \%$ of detached-house owners are expected to own a borehole.

Table 1: Distribution of proportion of households having drilled a borehole

\begin{tabular}{lcccccc}
\hline $\begin{array}{l}\text { Proportion of households equipped } \\
\text { with a borehole in municipalities }\end{array}$ & $0 \%$ & 0 to $1 \%$ & 1 to $10 \%$ & $10-25 \%$ & $25-50 \%$ & $>50 \%$ \\
\hline Number of municipalities in that class & 60 & 48 & 28 & 25 & 18 & 7 \\
\hline $\begin{array}{l}\text { Average threshold value } \\
\text { (in } \text { m }^{3} \text { year/household) }\end{array}$ & 2250 & 638 & 392 & 248 & 144 & 82 \\
\hline
\end{tabular}


Author-produced version of the article published in Ecological economics, 2011, 71, 140-150.

The original publication is available at http://www.sciencedirect.com

Doi: 10.1016/j.ecolecon.2011.08.018

One of the major shortcomings of the modeling approach presented above lies in the difficulty of calibrating and validating the model. Since no reliable borehole census exists, predicted figures cannot be compared with observed ones. The calibration of parameters such as the risk aversion or discount rate considered by households is therefore not possible, except for one municipality (Canet) where the number of boreholes is accurately estimated. To cope with the calibration problem, a sensitivity analysis was conducted to assess the robustness of the model (Figure 5). The results show that the model is quite stable. If we allow the risk-aversion coefficient to vary from 0.5 to 2 and the discount rate from zero to $3 \%$, the estimated number of tube wells varies from 6,000 to 8,700 .

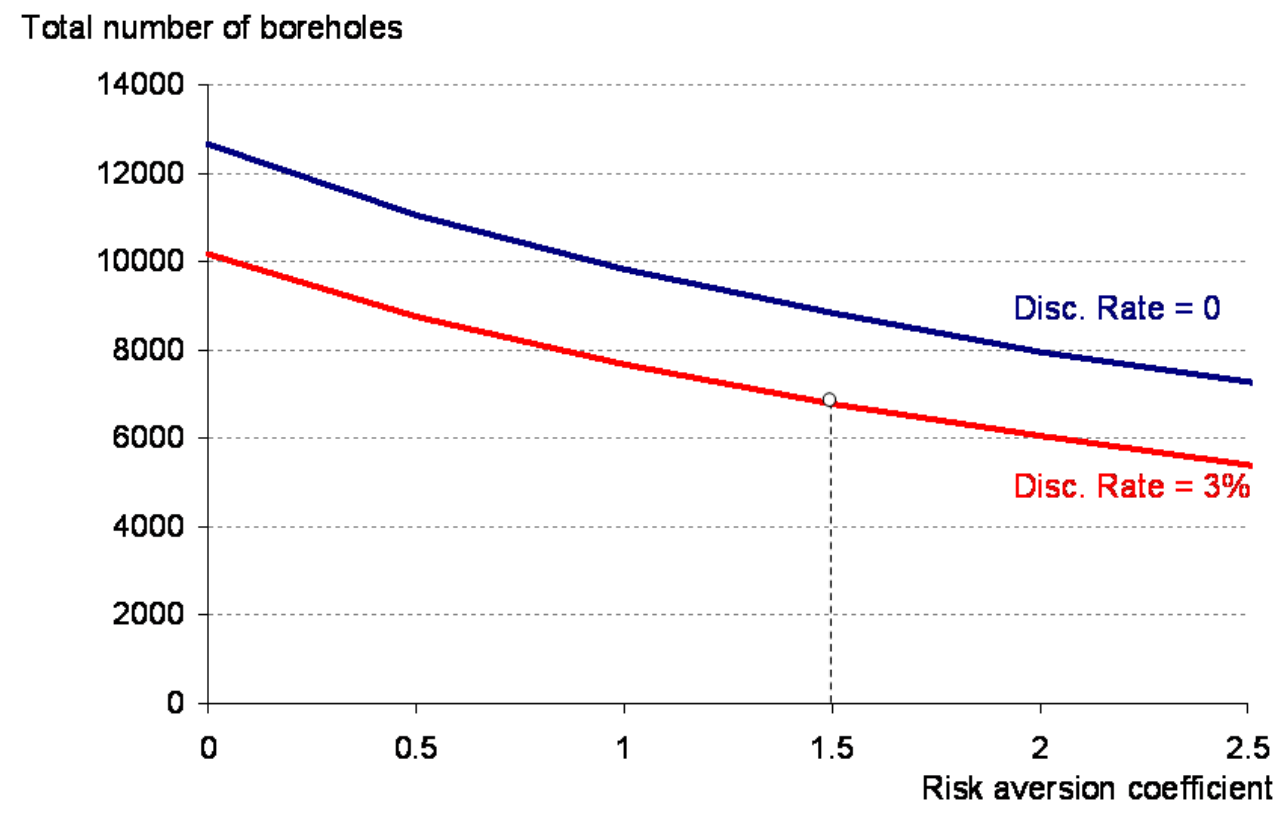

Figure 5: Sensitivity of the model to risk-aversion coefficient and discount rate 
Author-produced version of the article published in Ecological economics, 2011, 71, 140-150.

The original publication is available at http://www.sciencedirect.com

Doi: 10.1016/j.ecolecon.2011.08.018

\section{SIMULATING THE IMPACT OF POLICY SCENARIOS}

\subsection{Simulation methodology}

The economic model is then used to simulate the impact of economic changes expected to occur in the near future on the development of private tube wells. We first run the household decision model to assess the evolution of the profitability threshold considering different water pricing and drilling cost scenarios. We then run the water demand module to simulate the total number of tube wells constructed and the cumulative impact on municipal water demand.

One of the caveats of this simulation methodology is that it does not account for price elasticity of demand. Indeed, as price increases, households may adopt water conservation practices (fixing leaks, purchase of water efficient appliances, change in habits, etc.), which may bring their water demand below the profitability threshold. However, although the water demand profile depicted in figure 3 is likely to shift to the left, it was not possible, as part of the present study, to quantify this shift ${ }^{6}$.

\subsection{Expected change: towards an aggravation of the phenomenon}

Three drivers are likely to strengthen the economic incentives for households to drill private wells.

The first driver is water-price level, which is expected to increase in France and in other European countries. This trend is due to investments which still have to be made to meet the objectives of the new European regulations. French water utilities will have to undertake significant investments, estimated at $€ 27$ billion, to modernize wastewater-treatment plants and sewage systems in order to meet the objectives of the Urban Wastewater Directive by the year 2013. Significant investment (estimated at $€ 5$ billion) will also be needed to replace lead pipes in the public distribution system (Hrovatin and Bailey 2001). Moreover, municipalities 
Author-produced version of the article published in Ecological economics, 2011, 71, 140-150.

The original publication is available at http://www.sciencedirect.com

Doi: 10.1016/j.ecolecon.2011.08.018

must soon renew their water distribution systems, particularly in small municipalities such as those studied here, where no preventive maintenance has been carried out for decades. In the southeastern French river basin administrative district, the cost of system renewal is estimated at $€ 10$ billion over the next twenty years (Agence de l'Eau Rhône-Méditerranée-Corse 2002). In addition, the cost of water-resource protection and restoration measures imposed by the European Water Framework Directive will probably lead to an increase of extraction charges to cover the additional administrative and monitoring costs (Kallis and Butler 2001). We simulated the impact of various price-increase levels on the profitability threshold. Figure 6 shows that if marginal price is increased by $50 \%$, the profitability threshold decreases from 650 (point A) to $445 \mathrm{~m}^{3}$ (point $\mathrm{A}^{\prime}$ ) and the total number of boreholes increases by $56 \%$.

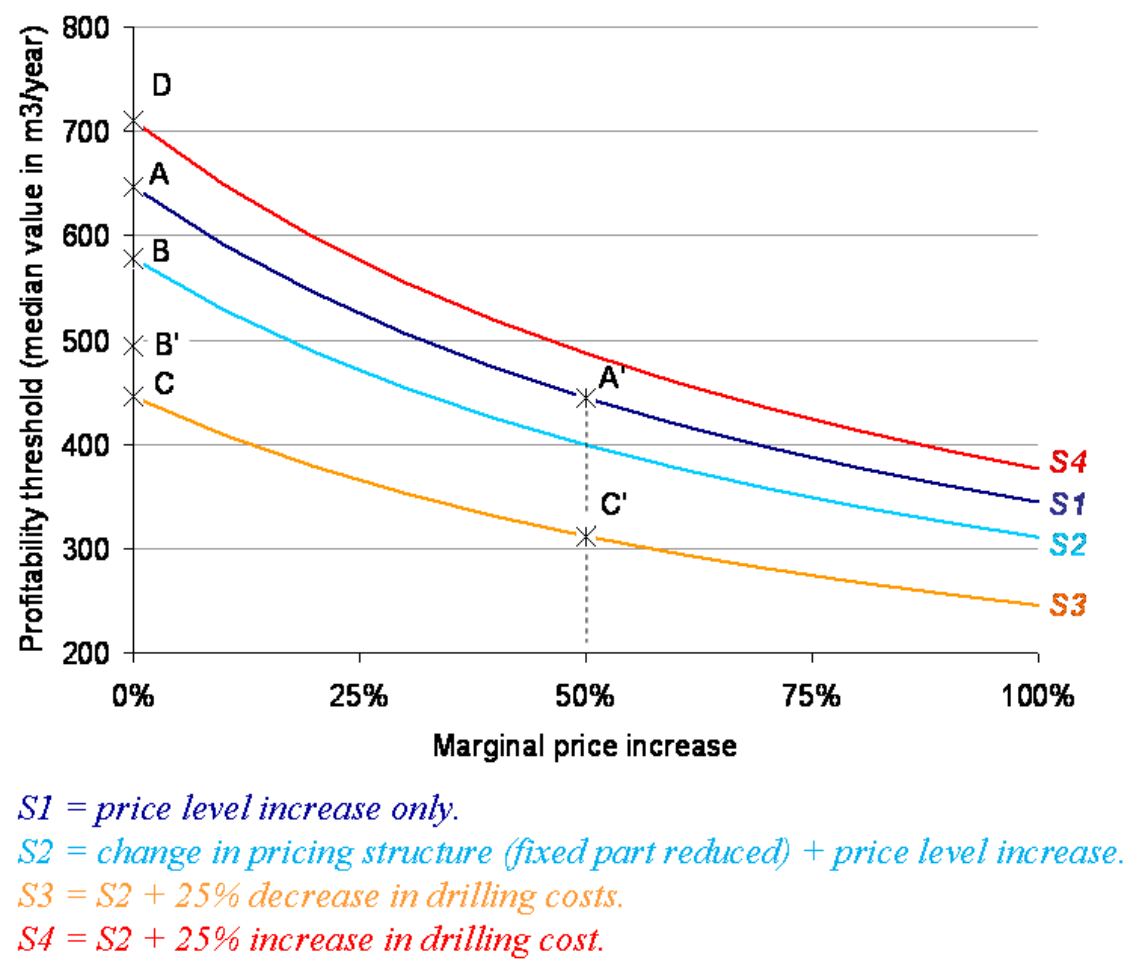

Figure 6: Variation of profitability threshold (in $\mathrm{m}^{3} / \mathrm{year} /$ household) with price increase, under various scenarios

\footnotetext{
${ }^{6}$ Not considering price elasticity results in over-estimating the number of households drilling a borehole, as some of them can simply implement water conservation measures instead of drilling a well (as our model would predict).
} 
Author-produced version of the article published in Ecological economics, 2011, 71, 140-150.

The original publication is available at http://www.sciencedirect.com

Doi: 10.1016/j.ecolecon.2011.08.018

The reform of tariffs imposed the new Water Law represents the second driver. Drinking Water Utilities are compelled to change their tariff structures to comply with the requirements of the 2006 French Water law. This law states that, after January 2010, the fixed part of the water bill must not exceed $30 \%$ of the total water bill (calculated for an average consumption of $120 \mathrm{~m}^{3} /$ household/year). This change in the water-pricing structure will automatically lead to an increase in the volumetric water price as water utilities have to balance their budget. Officials from Drinking Water Utilities were concerned that this would encourage households to drill. To simulate the impact of this change in tariff structure, we computed, for each municipality of our case study area, the new (increased) volumetric price that should be charged to compensate for a reduction of the fixed part of the bill as required by law. Using the model described in the previous sections, we then simulated the impact of this marginal price increase on tube well profitability. Results show that, in our case study area, this tariff reform will not significantly change incentives to drill: the median value of the profitability threshold decreases of $11 \%$ (shift from point A to B in figure 6) and to an increase of less than $1 \%$ of total number of tube wells. We further calculated that a complete elimination of the fixed part would lead to an increase of $24 \%$ in the total number of boreholes (point C in figure $6)$.

The third driver is drilling cost. If the number of drilling firms on the market continues to rise, increasing competition could result in a lower drilling cost (but also a reduction in borehole casing and cementing quality, with most of the boreholes not meeting the official quality standards). Based on expert advice, we assume that borehole drilling costs could be reduced by $25 \%$ if the French Government does not improve the inspection of private wellconstruction quality. Figure 6 shows that a 25\% drop of drilling cost would reduce the median profitability threshold from $650 \mathrm{~m}^{3} /$ year (point A) to 450 (point D). 
Author-produced version of the article published in Ecological economics, 2011, 71, 140-150.

The original publication is available at http://www.sciencedirect.com

Doi: 10.1016/j.ecolecon.2011.08.018

Altogether, if we assume a change in tariff structures (as required by the water law), a $25 \%$ decrease in drilling cost and 50\% increase of water price (situation depicted by point D'), the threshold declines from 650 to $310 \mathrm{~m}^{3} /$ household/year and the total number of tube wells increases by $100 \%$.

\subsection{Controlling drilling fever through regulation}

Symmetrically, increasing the cost of drilling is one way to control the development of boreholes. This can be achieved by imposing new regulations on drilling activities (implying a modification of the existing legislation) with a view to driving contractors that are not following bore-well construction standards out of business. This would not only reduce the negative environmental impacts described in the first part of this paper but also lead to an increase in the market price of drilling, thereby reducing the economic incentives for households to drill. As shown on figure 6, a $25 \%$ increase of drilling cost would raise the profitability threshold from 650 to $720 \mathrm{~m}^{3} / \mathrm{h} /$ year.

From an operational point of view, drilling companies could be licensed by the state, as is the case in Portugal, Australia, New Zealand, the USA, and Canada, where contractors have to pass a test demonstrating that they have the minimum required knowledge of geology and hydrogeology, drilling technologies, well-construction standards, and regulations required by their activity, and that the equipment they use meets existing standards. In France, given that less then one thousand companies specialized in drilling operate at the national level, the implementation of such a licensing system should not represent a major challenge for the Government.

Drilling companies would be made liable for damages to third parties or to the environment resulting from a failure to comply with tube-well construction standards. The quality of the construction would be checked upon completion by a site inspection, possibly using video cameras to inspect the well. Contractors would not only have to have general liability 
insurance but also deposit a cash bond or an irrevocable letter of credit corresponding to the cost of well abandonment, payable to a government agency. Such a system is already in force in most US states.

Finally, the current (ineffective) system of a posteriori declaration of water wells should be replaced by a system of permits which must be obtained before drilling, the permit specifying where and when the well will be drilled, each well being given an identification plate. Law enforcement could be strengthened by increased random checking of contractors and well owners and by an increased level of penalties (imprisonment and fines) as it is already the case in most US states and of Canada (for instance, unlicensed well drillers were fined \$24.000 in Ontario in 2002 and their licenses were revoked).

\subsection{Controlling drilling fever through pricing structure}

Another approach would consist of charging households for wastewater treatment, based on an actual measurement of water used indoors or on using a flat rate ${ }^{7}$. The flat rate being easier to implement and already used by some municipalities in France (for wastewater charge recovery), we simulated the impact of a generalization of this instrument. As shown in Figure 7, this would drastically reduce the profitability of boreholes (median and lower quartile). The profitability threshold (lower quartile) would increase from $225 \mathrm{~m}^{3} /$ year/household in the current situation to $350 \mathrm{~m}^{3} /$ year/household if wastewater treatment was charged on a flat rate basis.

\footnotetext{
${ }^{7}$ Charging wastewater on the basis of actual use indoors supposes that a separate meter be installed to measure the quantity of water used indoor and coming from the tube well. The enforcement of such a system would be very costly as Water Utilities would have to check that all water used indoors really passes through this meter and that there is no bypass. This is the reason why Water Utilities may prefer to charge wastewater using a flat rate for all households equipped with a tube well.
} 


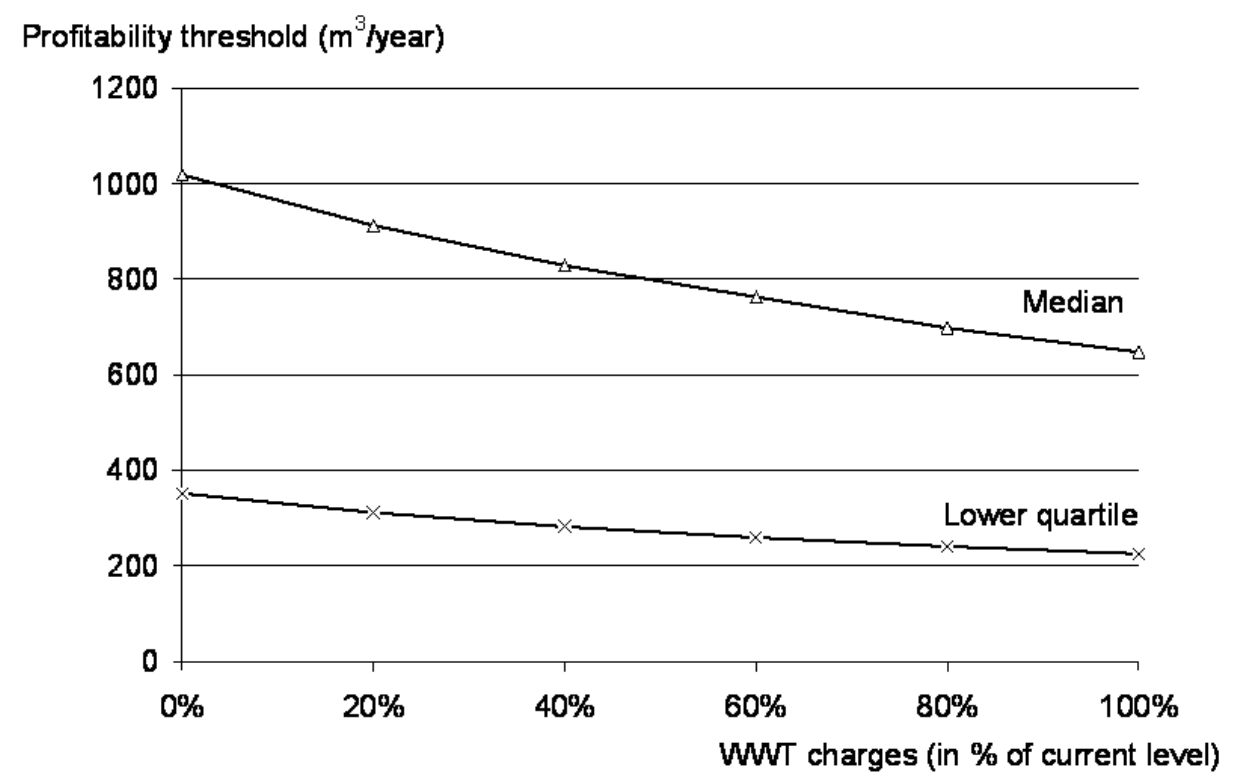

Figure 7: Variation of profitability threshold with decreasing wastewater charges

\section{DISCUSSION AND CONCLUSION}

The case of individual boreholes examined in this article throws light on an emerging phenomenon that is likely to take on greater significance in the majority of developed countries over the next few years. Increases in regulatory requirements regarding the treatment of drinking water and the purification of wastewater, along with the need to renew drinking-water and sewerage systems, will inevitably lead to a significant rise in the price of drinking water. This development is liable to encourage increasing numbers of domestic consumers to seek individual solutions for their water-supply needs. These could be individual boreholes, as in the case studied here, but also systems for recovering rainwater, systems for recycling graywater, or a combination of both systems. Because of the rather high price of water in Germany, systems for recovering rainwater were quickly developed, since they can pay for themselves over a period of five to seven years (Nolde 2005). 
Author-produced version of the article published in Ecological economics, 2011, 71, 140-150.

The original publication is available at http://www.sciencedirect.com

Doi: 10.1016/j.ecolecon.2011.08.018

These various arrangements for self-sufficiency of supply enable households that have the required investment capability to reduce the cost of their water supply, while at the same time continuing to benefit from the threefold security conferred by a connection to the municipal system: (1) they are assured of having an emergency resource available should their own system fail (technical fault or drought); (2) they benefit from the health security associated with the sophisticated treatment of their drinking water, which they can continue to use in small quantities for food and personal-hygiene purposes; and lastly, (3) they benefit from security against fire, since drinking-water systems have to be designed to deliver a flow sufficient for firefighting, whatever the demand from households connected to the system.

However, these households pay only a very small fraction of the costs associated with the provision of these three services. Most of the cost is therefore borne by the consumers who could not afford to invest in independent supply systems, who often happen to represent the most destitute households. In addition, these households see their water bills rising because of the water utility's obligation to balance its budget, and the service cost structure $(80 \%$ fixed costs on average). The implementation of incentive water rates thus leads to an accentuation of social inequalities, raising the question of the social sustainability of current charging and financing mechanisms.

Moreover, the growth of independent-supply strategies encouraged by incentive-pricing policies may lead to an increase in the pressures placed on water resources (except for the recycling of gray waters). In the case of the boreholes described in this article, households that have installed them will tend to consume more water (especially for outdoor use) after making their investment, since the incremental cost of directly-pumped water in the case studied here is only $€ 0.03 / \mathrm{m}^{3}$, versus $€ 2.2 / \mathrm{m}^{3}$ for drinking water. When the individual boreholes draw on the same resource as the public utility that produces the drinking water, the incentive pricing thus generates an increase in withdrawals, i.e., an effect that is exactly the opposite of what 
the higher prices were intended to achieve. Similarly, the widespread use of rainwaterrecovery systems can lead to a reduction in groundwater recharge, although such systems may also represent an opportunity, enabling a lessening of runoff waters and thereby reducing the impact of floods (Zaizen et al. 1999). The issue of social sustainability raised earlier thus goes hand in hand with a problem of environmental sustainability.

Studies addressing pricing seen as a tool for managing residential water demand often approach the problem in a rather narrow manner, avoiding discussion of the induced effects that we have just described. This is partly a consequence of the methods employed essentially econometric modeling, which, for want of available data, cannot take into account the emergence of individual supply strategies $^{8}$. We believe that our article makes a contribution by highlighting this problem. It also contributes to explaining the need to develop new ways for modeling demand, which take into account the discrete choices made by households. These include not only consumption choices but also choices of supply strategy.

From a policy perspective, there are two ways of addressing the issues that we have just described. The first, which we have illustrated in this article through the results of various simulations, consists of attempting to use the pricing or regulatory lever to control and limit the development of these strategies, at least in situations where they offer no benefits from the standpoint of the collective wellbeing. The second would involve the development of new financing mechanisms for public services, which would require all users to contribute in an equitable manner, according to the benefits that they obtain from the service. Overall, these issues can only be understood by developing an integrated vision of the smaller and greater water cycles, i.e., the management of services at the scale of the municipality (the water utility), and the management of resources at the scale of the catchment area or the aquifer.

\footnotetext{
${ }^{8}$ Water bill could explicitly distinguish charges for (1) firefighting service (fee proportional to the value of the house); (2) water connection fixed charge (corresponding to long term capital cost of water distribution infrastructure); (3) water consumption (proportional to the volume used, possibly charged with increasing blocks).
} 


\section{Acknowledgements}

This study has been supported by French National Research Agency (ANR) under the Sustainable Cities program (project EAU\&3E - grant number ANR-08-VILL-0007-05). The authors wish to thank Bernard Barraqué and Frédéric Grelot for interesting discussion on some of the issues addressed in this paper as well as two anonymous referees for their useful comments on an earlier version of this paper. However, the usual disclaimer applies.

\section{REFERENCES}

Agence de l'Eau Rhône-Méditerranée-Corse. 2002. Prix de l'eau en 2000-2001 dans le bassin RMC. Lyon.

Aguilera-Klink, F., E. Perez-Moriana, and J. Sanchez-Garcia. 2000. The social construction of scarcity. The case of water in Tenerife (Canary Islands). Ecological Economics 34:233-245.

Anderson, J. M. 2006. Integrating recycled water into urban water supply solutions. Desalination 187:1-9.

Appleyard, S. J., W. A. Davidson, and D. P. Commander. 1999. The effect of urban development on the utilization of groundwater resources in Perth, Western Australia. Pages 97-104 in J. C. Chilton, editor. Groundwater in Urban Environment. A.A. Balkema, Rotterdam.

Arbués, F., M. A. Garcia-Valinas, and R. Martinez-Espiñeira. 2003. Estimation of residential water demand: a state-of-the-art review. Journal of Socio-Economics 32:81-102.

Australian Bureau of Statistics. 2004. Domestic Water Use, Western Australia. in. http://www.abs.gov.au/Ausstats/abs@.nsf/0/30b03a00f823cc73ca256e6d007e4a11?OpenDoc ument.

Dalhuisen, J. M., R. J. G. M. Florax, H. L. F. de Groot, and P. Nijkamp. 2003. Price and income elasticities of residential water demand: a meta-analysis. Land Economics 79:292-308.

DGCCRF. 1999. Le point sur ... l'évolution des prix de l'eau, de 1991 à 1997. 17, Ministère de l'Economie, des Finances et de l'Industrie.

Espey, M., J. Espey, and W. D. Shaw. 1997. Price Elasticity of Residential Demand for Water: A Meta-Analysis. Water Resources Research 33:1369-1374.

European Commission. 2000. Pricing policy for enhancing the sustainability of water resources. $\operatorname{COM}(2000) 477$ final, European Commission, Brussels.

Freund, R. J. 1956. Introduction of risk into a programming model. Econometrica 24:253-263.

Herrington, P. 2001. Pricing and efficiency in the domestic water supply sector. Pages 203-211 in European Commission, editor. Pricing water: economics, environment and society. Office for Official Publications of the European Communities, Brussels.

Herrington, P. 2007. Waste not, want not? Water tariffs for sustainability. Report to WWF-UK.

Herrmann, T., and U. Schmida. 1999. Rainwater utilisation in Germany: efficiency, dimensioning, hydraulic and environmental aspects. Urban Water 1:307-316.

Hrovatin, N., and S. J. Bailey. 2001. Implementing the European Commission's water pricing communication: cross-country perspectives. Utilities Policy 10:13-24. 
IFEN. 2007. La facture d'eau domestique en 2004. 117, Le 4 pages de l'IFEN.

Jenkins, M. W., J. R. Lund, and R. E. Howitt. 2003. Using economic loss functions to value urban water scarcity in California. Journal of the American Water Works Association 95:58-70.

Kallis, G., and D. Butler. 2001. The EU water framework directive: measures and implications. Water Policy 3:125-142.

Kent, M., R. Newnham, and S. Essex. 2002. Tourism and sustainable water supply in Mallorca: a geographical analysis. Applied Geography 22:351-374.

Lazarova, V., S. Hills, and R. Birks. 2003. Using recycled water for non-potable, urban uses: a review with particular reference to toilet flushing. Water Science and Technology: Water Supply 3:69-77.

Markowitz, H. 1952. Portfolio Selection. Journal of Finance 7:77-91.

Meij, S. H. F. M., C. J. M. Ruiters, and J. C. J. Stumphius. 2005. Market-driven pricing structures for drinking water. Water Science and Technology: Water Supply 5:225-233.

Miquel, G., and H. Revol. 2003. La qualité de l'eau et de l'assainissement en France. Tome 1 (20022003) 215 , Office parlementaire d'évaluation des choix scientifiques et technologiques.

Montginoul, M., P. Garin, and M. Ladki. 2009. La présence d'un réseau de distribution d'eau brute dans une commune : un facteur d'amélioration du bien-être collectif ? Economie Rurale 310:57-73.

Nauges, C., and A. Thomas. 2003. Long-run Study of Residential Water Consumption. Environmental and Resource Economics 26:25-43.

Nolde, E. 2005. Greywater recycling systems in Germany--results, experiences and guidelines. Water Science \& technology 51:203-210.

OECD. 1999. The price of water - Trends in OECD countries.

OECD. 2010. Pricing water resources and water and sanitation services. OECD, Paris.

Ortiz, E. M., J. F. Langowski, B. Dziegielewski, N. A. Hanna-Somers, J. S. Wilett, and R. J. Hauer. 1997. Forecasting urban water use: models and applications. in D. D. Baumann, J. J. Boland, and W. M. Hanemann, editors. Urban Water Demand Management and Planning. Mc Graw Hill.

Reynaud, A., and C. Nauges. 2010. How much water do residential users really need ? An estimation of minimum water requirements for French households. Pages 24 in Paper presented at the World Congress of Environmental and Resource Economists, Montreal, Canada.

Rinaudo, J.-D., N. Neverre, and M. Montginoul. forthcoming. Simulating the impact of pricing policies on urban water demand : a Southern France case study. Water Resources Management.

Rogers, P., R. de Silva, and R. Bhatia. 2002. Water is an economic good: How to use prices to promote equity, efficiency, and sustainability. Water Policy 4:1-17.

Rosenberg, D. E., T. Tarawneh, R. Abdel-Khaleq, and J. R. Lund. 2007. Modeling integrated water user decisions in intermittent supply systems. Water Resour. Res. 43:W07425.

Saayman, I. C., and S. Adams. 2002. The use of garden boreholes in Cape Town, South Africa: lessons learnt from Perth, Western Australia. Physics and Chemistry of the Earth, Parts A/B/C 27:961-967.

Schleich, J., and T. Hillenbrand. 2009. Determinants of residential water demand in Germany. Ecological Economics 68:1756-1769.

Sociology Water Lab, and Colorado Institute for Irrigation Management. 2003. The benefits and costs of pressurized dual water systems in Colorado and the potential role of canal companies and 
irrigation districts in providing the pressurized irrigation water supply portion of dual systems. Colorado State University, USA.

Worthington, A. C., and M. Hoffman. 2008. An Empirical Survey of Residential Water Demand Modelling. Journal of Economic Surveys 22:842-871.

Zaizen, M., T. Urakawaa, Y. Matsumotoa, and H. Takaib 1999. The collection of rainwater from dome stadiums in Japan. Urban Water 1:355-359. 